\title{
ASMENŲ, GAVUSIŲ KAUNO MIESTO SAVIŽUDYBIŲ PREVENCIJOS MODELIO PASLAUGAS, POŽIŪRIS İ PAGALBOS VEIKSMINGUMĄ
}

\author{
Laura Digryte் ${ }^{1,2}$, Lina Pranckevičiūtè $\dot{1}^{1}$ Gerda Kuzmarskienè ${ }^{1}$ \\ ${ }^{1}$ Kauno miesto savivaldybès visuomenès sveikatos biuras, ${ }^{2}$ Lietuvos sveikatos mokslu universitetas
}

Raktažodžiai: savižudybès, prevencija, psichosocialinès paslaugos, pagalbos gavejjai, veiksmingumas.

\section{Santrauka}

Tikslas - įvertinti asmenų, gavusių Kauno miesto savižudybiu prevencijos modelio paslaugas, požiūrị i suteiktą pagalbą ir jos veiksmingumą.

Tyrimo metodika. Tyrimas atliktas kiekybinès anketinès apklausos būdu 2019 metų gegužès-rugpjūčio mènesiais įstaigose, kuriose teikiamos Kauno miesto savižudybių prevencijos modelio paslaugos. Kiekybinè tyrimo anketa sudaryta iš klausimų, skirtų surinkti duomenis apie socialinius-demografinius rodiklius, savižudybès grèsmę, paslaugų gavimo ypatumus, pasitenkinimą paslaugomis bei požiūrị i jų poveikị. Tiriamujų atsakymai buvo apdoroti ir analizuojami „Microsoft Excel 2007“ ir „IBM SPSS 20.0“ programomis.

Rezultatai ir išvados. Dauguma Kauno miesto savižudybių prevencijos modelio paslaugas gavusių tyrimo dalyvių atvejo vadybą, psichologines ar savitarpio pagalbos grupes ir anonimines psichologo konsultacijas vertino teigiamai. Daugiausia atvejo vadybos paslaugą išbandžiusių asmenų pastebèjo teigiamus pokyčius, gaunant emocinę paramą, žinias, kur galima kreiptis pagalbos ir mažinant mintis apie savižudybę, o mažiausiai pastebejjusių teigiamus pokyčius buvo sprendžiant problemas, gerinant bendravimo ịgūdžius ir asmeninius santykius. Psichologinėse arba savitarpio pagalbos grupèse dalyvavę asmenys daugiausia teigiamu pokyčiu pastebėjo gaunant emocinę paramą, žinias, kur galima kreiptis pagalbos ir didinant viltị, kad pavyks išspręsti sunkumus, o mažiausiai pastebejusių teigiamus pokyčius buvo mažinant nerimą ir stresą, sprendžiant problemas, gerinant asmeninius santykius. Daugiausia anonimines psichologo konsultacijas gavusių asmenų pastebejo teigiamus pokyčius, gaunant emocinę paramą, didinat viltí, kad pavyks išspręsti sunkumus ir gerinant emocinę savijautą, o mažiausiai pastebejjusių teigiamus pokyčius buvo gerinant asmeninius santykius, bendravimo ịgūdžius, sprendžiant problemas.

\section{Ivadas}

Savižudybė yra procesas, apimantis tokius etapus, kaip minčių, ketinimų, planų apie savižudybę atsiradimas, kuris gali baigtis savo gyvybès nutraukimo veiksmu [1]. Pastebima, kad savižudiškas elgesys skiriasi priklausomai nuo lyties, amžiaus grupès, geografinio regiono ir socialinès ar politinès aplinkos. Bandžiusieji nusižudyti asmenys dažniausiai yra vieniši, žemesnio išsilavinimo, gaunantys mažesnes pajamas, nedirbantys ir pasižymintis prastesniais gyvenimo kokybės rodikliais [2]. Klinikinejje praktikoje nèra vieno bendro veiksmingo pagalbos savižudybės grèsmès atveju algoritmo, todèl kuo geresnis klinikinių, psichologinių, socialinių ir biologinių veiksnių atpažinimas ir jų supratimas gali padèti atpažinti didelèje savižudybės rizikoje esančius asmenis, rekomenduoti tinkamą gydymą bei psichosocialinę pagalbą, o teikiamos pagalbos vertinimas - siekti geresnès jos kokybès [3].

Mokslinèje literatūroje išskiriami tokie pagrindiniai savižudybių prevencijos programų aspektai, kaip pagerinti depresijos gydymo metodus, paslaugų prieinamumą, sumažinti prieigą prie savižudybę skatinančių priemonių ir išvengti Werther efekto [4]. Veiksmingiausiomis savižudybės intervencijomis įvardinamos savižudybę skatinančių priemonių apribojimas, kontakto su pacientais palaikymas po stacionarinio gydymo ir pagalbos skambučių centrų darbas [5]. Siekiant pagerinti žinias, susijusias su stigma, problemų sprendimu ir požiūriu, svarbu plètoti socialinius kontaktus, puoselèti tarpusavio bendravimą bei užtikrinti pagalbos prieinamumą ir tinkamumą [6].

Lietuvoje savižudybių prevencija ir paslaugų prieinamumo užtikrinimas tampa prioritetine kryptimi dèl šio reiškinio rodiklių. 2017 metais Lietuvoje užregistruotas didžiausias savižudybių skaičius Europoje (27,99 atvejai/100 
tūkst. gyventojų) [7]. Atsižvelgiant ị tokią situaciją, 2017 metais imtasi iniciatyvos įdiegti Kauno miesto savižudybių prevencijos modeli, aprépiantị atvejo vadybos paslaugos diegimą, psichologinių grupių bei anoniminių psichologiniu konsultacijų prieinamumo didinimą. Siekiant efektyvios savižudybių prevencijos, stebetas poreikis išanalizuoti požiūrị i gaunamų paslaugų veiksmingumą.

Darbo tikslas - įvertinti asmenų, gavusių Kauno miesto savižudybių prevencijos modelio paslaugas, požiūrị ị suteiktą pagalbą ir jos veiksmingumą.

\section{Tyrimo medžiaga ir metodai}

Tyrimui atlikti gautas raštiškas Kauno regioninio biomedicininių tyrimų etikos komiteto leidimas (Nr. BE-2-45). Tyrimas atliktas Kauno savižudybių prevencijos modelio veiklas igyvendinančiose įstaigose: Kauno miesto poliklinikos psichikos sveikatos centruose, viešosiose įstaigose „Moters pagalba moteriai“, „Psichologinés paramos ir konsultavimo centras", Respublikinès Kauno ligoninès Krizių intervencijos centre, Kauno apskrities vyrų krizių centre, asociacijoje „Artimiems“. Tyrimo pobūdis - kiekybinè anketinè apklausa, vykdyta nuo 2019 metu gegužès pradžios iki rugpjūčio pabaigos. Pagalbą gaunantys asmenys pildè informuoto asmens sutikimo formą, o pasirašytą perduodavo pagalbos teikèjams, kurie sukauptas informuoto asmens sutikimo formas perduodavo viename voke. Užpildytą anketą pagalbos gavejjas perduodavo tyrëjams (per pagalbos teikèjus), pats užklijuodamas tyrejjų antspauduotą voką. Šis apklausos būdas pasirinktas kaip saugiausias užtikrinti pagalbos gavėjų konfidencialumą ir tiriamujų anonimiškumą, bei sumažinti pagalbos teikèjų poveiki apklausos rezultatams.

Kiekybinè tyrimo anketa sudaryta iš klausimų, skirtu surinkti duomenis apie socialinius-demografinius rodiklius (lytis, amžius), savižudybės grèsmę (su savižudybe susijusios mintys, ketinimai, planai), paslaugų gavimo ypatumus (gautų paslaugų tipas, dažnumas). Likert skalëje vertintas pasitenkinimas paslaugomis ( 1 - labai blogai, 2 - blogai, 3 - vidutiniškai, 4 - gerai, 5 - labai gerai) ir požiūris ị gautų paslaugų veiksmingumą pagal autorių sudarytą klausimyną

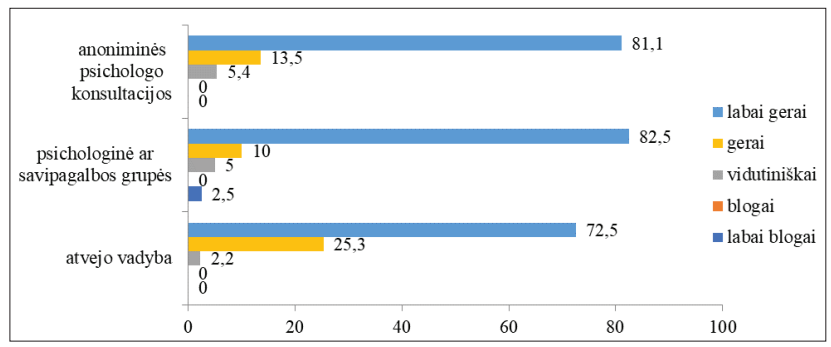

1 pav. Suteiktų paslaugų poveikio vertinimas (respondentų nuomonè), proc.
( 1 - visiškai ne, 2 - labiau ne nei taip, 3 - nei taip, nei ne, 4 - labiau taip nei ne, 5 - visiškai taip). Klausimynas sudarytas iš asmenų, pasinaudojusių konkrečia paslauga (atvejo vadybos, psichologinès, savitarpio paramos grupių ar anonimine psichologo konsultacija), patyrimo apibendrinimo: pagerejusi emocinè savijauta, gauta reikalinga emocinè parama, sumažèjęs nerimas ir (ar) stresas, padidejjusios galimybès aktyviai spręsti problemas, atsiradusi viltis, kad pavyks išspręsti sunkumus, pagerinti asmeninius santykius, bendravimo ịgūdžius, ịgyta žinių, kur kreiptis pagalbos esant prastai emocinei savijautai, pozityvesnis požiūris ị ateitị, mažiau minčių apie savižudybę, neliko ketinimų nusižudyti. Pastebėję teigiamus pokyčius grupuoti pagal atsakymus "visiškai taip" ir "labiau taip nei ne", o nepastebejję teigiamų pokyčių grupuoti pagal atsakymus "visiškai ne", "labiau ne nei taip" ir "nei taip, nei ne".

Tiriamujų atsakymai buvo apdoroti ir išanalizuoti „,Microsoft Excel 2007“ ir „IBM SPSS 20.0“ programomis. Grafinių duomenų pateikimui naudota Microsoft Excel programa. Atliekant aprašomają statistikos dali, vidutinė padètis buvo vertinama vidurkiu, reikšmių sklaida - standartiniu nuokrypiu, o atsakymų paplitimas ir pasiskirstymas - minimalia ir maksimalia reikšme arba procentais ir absoliučiais skaičiais.

\section{Rezultatai}

Atliekant pagalbos gavėjų požiūrio i̇ gautų paslaugų veiksmingumą analizę, surinktos 132 anketos. Tyrime dalyvavo 66,7 proc. moteru $(n=88)$ ir 33,3 proc. vyrų $(n=44)$.

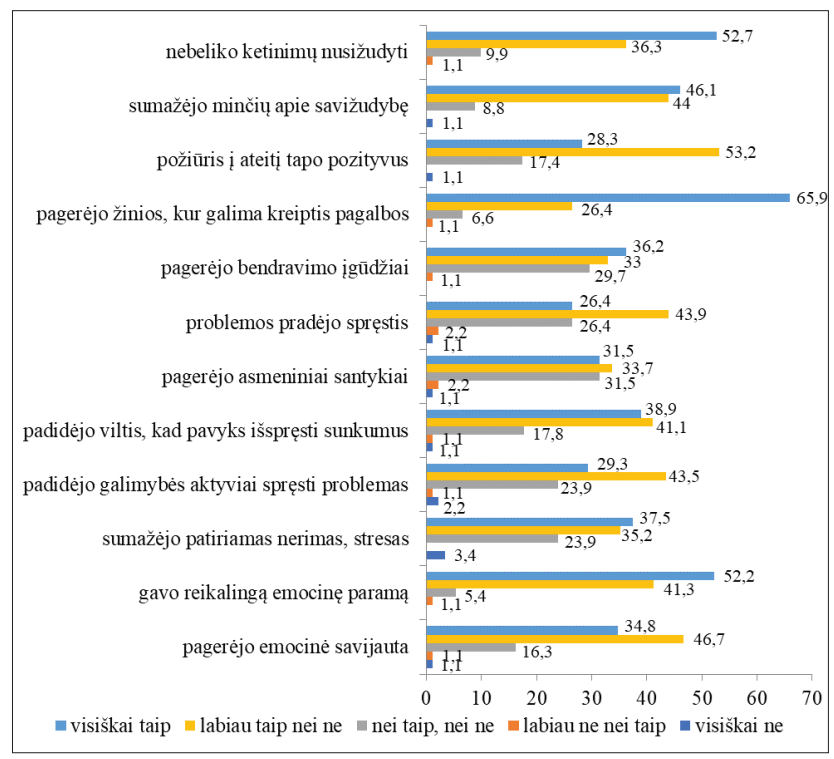

2 pav. Atvejo vadybos paslaugų poveikio vertinimas (respondentų nuomonè), proc. 
Tiriamujų amžius buvo nuo 18 iki 82 metų, amžiaus vidurkis $-38,9 \pm 13,49$.

Dauguma (90,2 proc., $\mathrm{n}=119)$ pagalbos gavèjų teigè turèję minčių apie savižudybę, kiek daugiau nei pusè $(66,7$ proc., $\mathrm{n}=88)$ - kūrę savižudybès planus, trečdalis ( 31,8 proc., $\mathrm{n}=42$ ) buvo bandę nusižudyti.

Daugiau nei pusè ( 71,2 proc., $n=94)$ tyrimo dalyvių gavo atvejo vadybos paslaugas, kiek mažiau nei trečdalis $(28,8$ proc., $n=38$ ) dalyvavo psichologinèse grupèse, mažiau nei trečdalis $(28,8$ proc., $\mathrm{n}=38)$ gavo anonimines psichologo paslaugas. Mažiausiai (1,5 proc., $\mathrm{n}=2)$ respondentų dalyvavo nusižudžiusiųų artimujjų grupeje. Anoniminėmis psichologo konsultacijomis naudojosi: 3-4 kartus 47,2 proc. ( $\mathrm{n}=17)$ tyrimo dalyviu, 5-10 kartu $-22,2$ proc. $(n=8)$, daugiau nei 10 kartu $-16,7$ proc. $(n=6), 1-2$ kartus $-13,9$ proc. $(n=5)$ apklaustujų. Psichologinėse grupėse 76,3 proc. $(n=29)$ dalyvavo daugiau nei 10 kartu, 10,5 proc. $(\mathrm{n}=4)-5-10$ kartų, 7,9 proc. $(\mathrm{n}=3)-3-4$ kartus, 5,3 proc. $(\mathrm{n}=2)-1-2$ kartus. Atvejo vadybos paslaugas gavo 53,3 proc. $(n=48)$ daugiau nei 10 kartų, 23,3 proc. $(\mathrm{n}=21)-5-10$ kartų, 16,7 proc. $(\mathrm{n}=15)-3-4$ kartus, 6,7 proc. $(\mathrm{n}=6)-1-2$ kartus. Dalyvavo nusižudžiusių artimųu grupèje 50 proc. $(\mathrm{n}=1)$ nuo 5 iki 10 grupinių užsièmimų ir 50 proc. $(\mathrm{n}=1)$ daugiau nei 10 kartų.

Remiantis gautų paslaugų vertinimo anketų rezultatais, dauguma Kauno miesto savižudybių prevencijos modelio

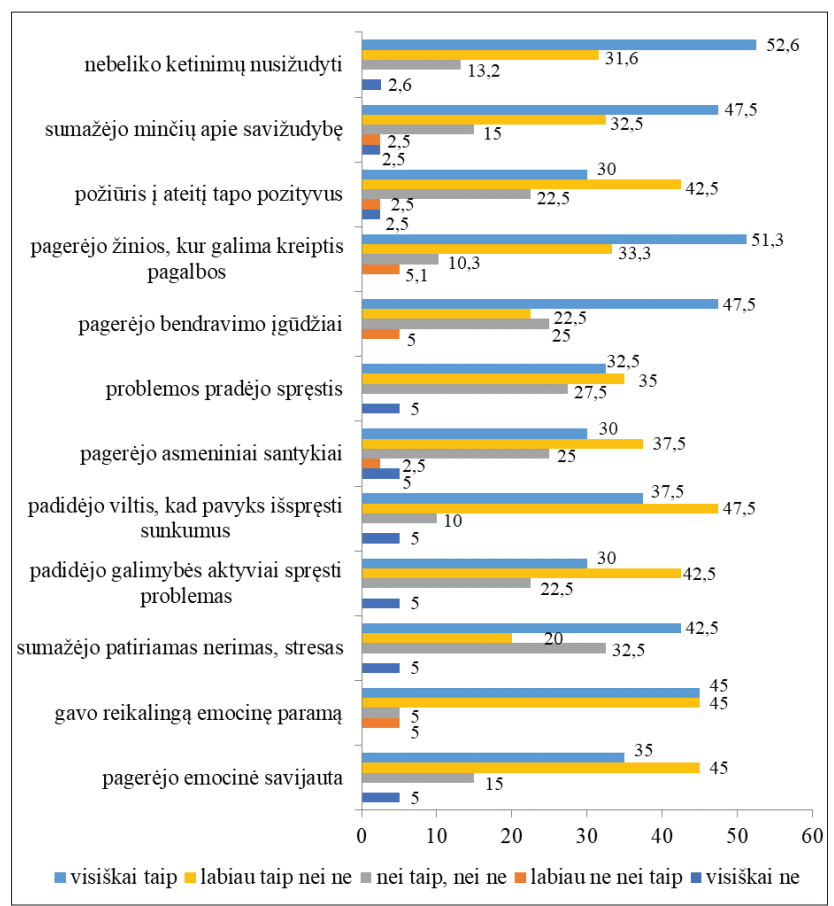

3 pav. Psichologinių arba savitarpio pagalbos grupių susitikimu poveikio vertinimas (proc.) paslaugas gavusių asmenų jas vertino teigiamai (gerai arba labai gerai). Iš atskiras paslaugas gavusių tyrimo dalyvių atvejo vadybą teigiamai ịvertino 97,8 proc. $(n=89)$, anonimines psichologo konsultacijas - 94,6 proc. $(n=35)$, psichologines arba savitarpio pagalbos grupes $-92,5$ proc. $(n=37)$ (1 pav.).

Dauguma tyrimo dalyvių, pasinaudojusių atvejo vadybos paslauga, teigè pastebeję teigiamus savijautos ar situacijos pokyčius: gavo reikalingą emocinę paramą $(93,5$ proc., $\mathrm{n}=86)$, sužinojo, kur galima kreiptis pagalbos $(92,3$ proc., $n=84)$, sumažèjo minčių apie savižudybę $(90,1$ proc., $\mathrm{n}=82$ ), nebeliko ketinimų nusižudyti ( 89 proc., $n=81$ ), pagerèjo emocinè savijauta $(81,5$ proc., $n=75)$, požiūris i it ateitị tapo labiau pozityvus ( 81,5 proc., $n=75)$, padidejo viltis, kad pavyks išspręsti sunkumus ( 80 proc., $\mathrm{n}=72$ ), padidèjo galimybès aktyviai spręsti problemas $(72,8$ proc., $n=67)$, sumažejo nerimas ir stresas $(72,7$ proc., $n=64)$, problemos pradèjo spręstis (70,3 proc., $\mathrm{n}=64)$, pagerèjo bendravimo igūdžiai $(69,2$ proc., $n=63)$, pagerèjo asmeniniai santykiai $(65,2$ proc., $\mathrm{n}=60)(2$ pav.).

Vis dèlto ir pasinaudoję atvejo vadybos paslaugomis, 34,8 proc. $(\mathrm{n}=32)$ tyrimo dalyvių išreiškè nuomonę, kad nepastebèjo teigiamų pokyčių, susijusių su asmeninių santykių pagerejjimu, 30,8 proc. $(\mathrm{n}=28)$ - su bendravimo ịgūdžių

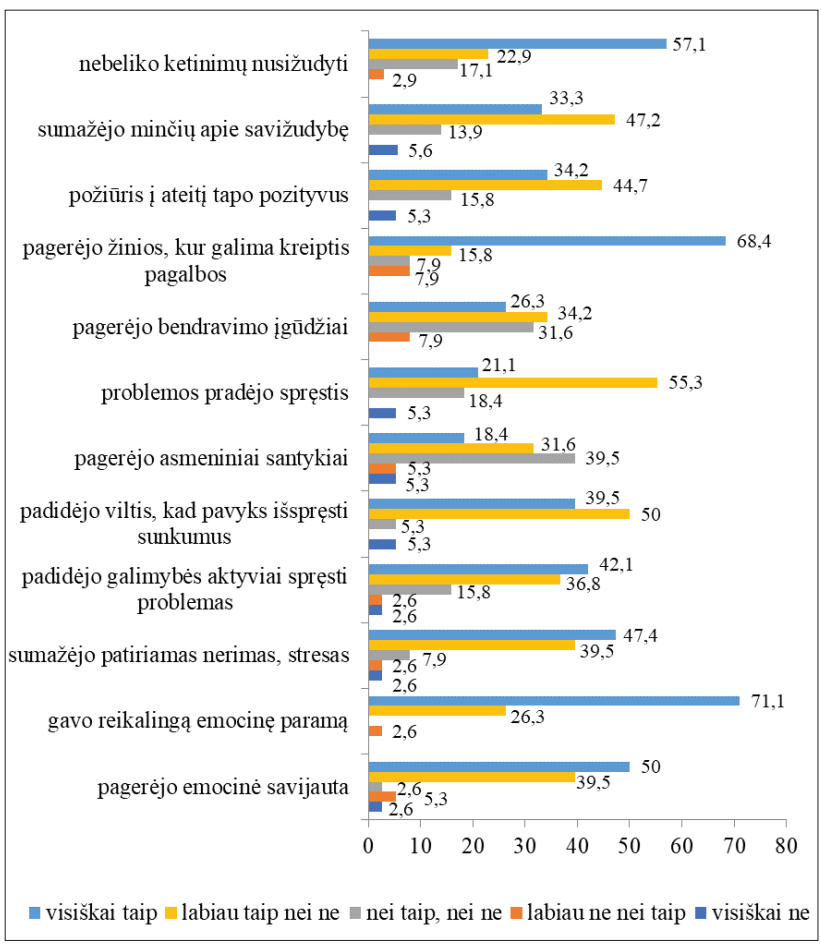

4 pav. Anoniminių psichologinių konsultacijų poveikio vertinimas (proc.) 
pagerèjimu, 29,7 proc. $(\mathrm{n}=27)$ - su problemų sprendimu, 27,3 proc. $(n=24)$ - su nerimo ir streso sumažejimu, 27,2 proc. $(\mathrm{n}=25)$ - su padidejusiomis galimybėmis aktyviai spręsti problemas, 20 proc. $(\mathrm{n}=18)$ - su vilties, kad pavyks išspręsti sunkumus, padidejjimu, 18,5 proc. $(\mathrm{n}=17)$ - su pozityvesniu požiūriu ị ateitị, 18,5 proc. $(\mathrm{n}=17)$ - su emocinès savijautos pagerejjimu, 11 proc. $(\mathrm{n}=10)$ - su ketinimų nusižudyti sumažjejimu, 9,9 proc. $(\mathrm{n}=9)$ - su minčių apie savižudybę sumažejimu, 7,7 proc. $(n=7)$ - su žinių, kur galima kreiptis pagalbos, pagerejimu, 6,5 proc. $(\mathrm{n}=6)-$ su emocinès paramos gavimu (2 pav.).

Dauguma tyrimo dalyvių, lankęsi psichologinèse arba savitarpio pagalbos grupèse, teigè pastebèję šiuos teigiamus pokyčius: gavo reikalingą emocinę paramą $(92,1$ proc., $\mathrm{n}=36$ ), pagerejjo žinios, kur galima kreiptis pagalbos $(84,2$ proc., $\mathrm{n}=33$ ), padidejjo viltis, kad pavyks išspręsti sunkumus ( 84,2 proc., $n=34)$, nebeliko ketinimų nusižudyti $(83,4$ proc., $\mathrm{n}=32$ ), sumažèjo minčių apie savižudybę (79 proc., $\mathrm{n}=32$ ), pagerèjo emocinè savijauta $(78,9$ proc., $n=32)$, požiūris i ateitị tapo labiau pozityvus $(71,1$ proc., $n=29)$, padidèjo galimybès aktyviai spręsti problemas ( 71,1 proc., $n=29)$, pagerèjo bendravimo ịgūdžiai $(68,5$ proc., $n=28)$, pagerèjo asmeniniai santykiai $(65,8$ proc., $n=27)$, problemos pradejo spręstis $(65,8$ proc., $n=27)$, sumažèjo nerimas ir stresas $(63,1$ proc., $\mathrm{n}=25)$ ( 3 pav.).

Vis dèlto po psichologinių ar savitarpio pagalbos grupių užsièmimų 36,9 proc. $(\mathrm{n}=15)$ tyrime dalyvavusių ir nuomonę išreiškusių asmenų nepastebejjo teigiamų pokyčių, susijusių su nerimo ir streso sumažejimu, 34,2 proc. $(n=13)$ - su problemų sprendimu, 34,2 proc. $(\mathrm{n}=13)$ - su asmeninių santykių pagerèjimu, 31,5 proc. $(\mathrm{n}=12)$ - su bendravimo igūdžių pagerèjimu, 28,9 proc. $(\mathrm{n}=11)$ - su padidejjusiomis galimybėmis aktyviai spręsti problemas, 28,9 proc. $(\mathrm{n}=11)$ - su pozityvesniu požiūriu į ateitị, 21,1 proc. $(n=8)-$ su emocinès savijautos pagerèjimu, 21 proc. $(n=8)$ - su minčiu apie savižudybę sumažèjimu, 16,6 proc. $(\mathrm{n}=6)$ - su ketinimų nusižudyti sumažejjimu, 15,8 proc. $(\mathrm{n}=6)$ - su vilties, kad pavyks išspręsti sunkumus, padidejimu, 15,8 proc. $(\mathrm{n}=6)-$ su žinių, kur galima kreiptis pagalbos, pagerèjimu, 7,9 proc. $(\mathrm{n}=4)$ - su emocinès paramos gavimu (3 pav.).

Dauguma tyrimo dalyvių, išreiškusių nuomonę po anoniminių psichologo konsultacijų, teigè pastebėję teigiamus pokyčius: gavo reikalingą emocinę paramą (97,4 proc., $n=37)$, padidèjo viltis, kad pavyks išspręsti sunkumus $(89,5$ proc., $\mathrm{n}=34)$, pagerèjo emocinè savijauta $(89,5$ proc., $n=34)$, sumažèjo nerimas ir stresas ( 86,9 proc., $n=33$ ), pagerèjo žinios, kur galima kreiptis pagalbos $(84,2$ proc., $n=32)$, sumažejo minčių apie savižudybę ( 80,5 proc., $n=29)$, nebeliko ketinimo nusižudyti ( 80 proc., $n=28)$, požiūris ị ateitị tapo labiau pozityvus ( 78,9 proc., $n=30)$, padidèjo galimybès aktyviai spręsti problemas ( 78,9 proc., $n=30)$, problemos pradèjo spręstis $(76,4$ proc., $n=29)$, pagerèjo bendravimo ịgūdžiai $(60,5$ proc., $n=23)$, pagerèjo asmeniniai santykiai (50 proc., $\mathrm{n}=19)(4$ pav.).

Vis dèlto po anoniminiu psichologo konsultacijų 50 proc. $(n=19)$ tyrime dalyvavusių ir nuomonę išreiškusių asmenų nepastebėjo teigiamų pokyčių, susijusių su asmeninių santykių pagerèjimu, 39,5 proc. $(n=15)$ - su bendravimo ịgūdžių pagerèjimu, 23,6 proc. $(\mathrm{n}=9)$ - su problemų sprendimu, 21,1 proc. $(\mathrm{n}=8)$ - su padidèjusiomis galimybèmis aktyviai spręsti problemas, 21,1 proc. $(n=8)$ - su pozityvesniu požiūriu i ateiti, 20 proc. $(n=7)$ - su ketinimais nusižudyti, 19,5 proc. $(n=7)$ - su minčiu apie savižudybę sumažèjimu, 15,8 proc. $(\mathrm{n}=6)$ - su žinių, kur galima kreiptis pagalbos pagerejjimu, 13,1 proc. $(\mathrm{n}=5)$ - su nerimo ir streso sumažèjimu, 10,5 proc. $(n=4)$ - su emocinès savijautos pagerejimu, 10,5 proc. $(n=4)$ - su vilties, kad pavyks išspręsti sunkumus, padidejjimu, 2,4 proc. $(\mathrm{n}=1)$ - su emocinès paramos gavimu (4 pav.).

\section{Išvados}

1. Dauguma asmenų, gavusių Kauno miesto savižudybių prevencijos modelio paslaugas, teigiamai ịvertino atvejo vadybą, dalyvavimą psichologinèse ar savitarpio pagalbos grupèse ir anonimines psichologo konsultacijas.

2. Daugiausia atvejo vadyboje dalyvavusių asmenų teigè pastebèję teigiamus pokyčius gaunant emocinę paramą, žinias, kur galima kreiptis pagalbos ir sumažinant mintis apie savižudybę, o daugiausia nepastebejjusių teigiamų pokyčių buvo sprendžiant problemas, gerinant bendravimo igūdžius ir asmeninius santykius.

3. Daugiausia psichologinèse arba savitarpio pagalbos grupėse dalyvavusių asmenų teigè pastebèję teigiamus pokyčius gaunant emocinę paramą, žinių, kur kreiptis pagalbos ir didinant viltị, kad pavyks išspręsti sunkumus, o daugiausia nepastebejjusių teigiamų pokyčiu buvo mažinant nerimą ir stresą, sprendžiant problemas, gerinant asmeninius santykius.

4. Daugiausia anonimines psichologo konsultacijas gavusiu asmenu pastebėjo teigiamus emocinius pokyčius, padidino viltis išspręsti sunkumus ir pagerinti emocinę savijautą, o daugiausia nepastebẻjusių teigiamų pokyčių buvo gerinant asmeninius santykius, bendravimo ịūdžius, sprendžiant problemas.

\section{Literatūra}

1. Gailienė D. Savižudybių prevencijos Lietuvoje gairès. Vilnius, 2001; 9-30.

2. Alves VdM, Francisco LCFdL, Belo FMP, de-Melo-Neto VL, Barros VG, Nardi AE. Evaluation of the quality of life and risk of suicide. Clinics 2016;71(3):135-139.

https://doi.org/10.6061/clinics/2016(03)03 
3. Turecki G, Brent DA. Suicide and suicidal behaviour. Lancet 2016;387(10024):1227-1239. https://doi.org/10.1016/S0140-6736(15)00234-2

4. Hegerl U. Prevention of suicidal behaviour. Dialogues in Clinical Neuroscience 2016;18(2):183.

5. Du Roscoät E, Beck F. Efficient interventions on suicide prevention: a literature review. Revue d'epidemiologie et de Sante Publique 2013;61(4):363-374. https://doi.org/10.1016/j.respe.2013.01.099

6. Thornicroft G, Mehta N, Clement S, Evans-Lacko S, Doherty M, Rose D, Henderson C. Evidence for effective interventions to reduce mentalhealth-related stigma and discrimination. Lancet 2016;387(10023):1123-1132. https://doi.org/10.1016/S0140-6736(15)00298-6

7. Global burden of disease study 2017 (GBD 2017). Results. Institute Health Metrics Evaluation 2018.

\section{THE APPROACH TO THE EFFECTIVENESS OF RECEIVED PSYCHOSOCIAL HELP FROM KAUNAS CITY SUICIDE PREVENTION MODEL SERVICES} L. Digrytė, L. Pranckevičiūtė, G. Kuzmarskienė

Keywords: suicides, prevention, psychosocial services, aid recipients, effectiveness.

Summary

The aim of the study: To evaluate the approach of the persons receiving Kaunas city suicide prevention model services to the received psychosocial help and its' effectiveness.

Methods. The research was conducted from May to August 2019 in organizations, which provide services of Kaunas city suicide prevention model. The quantitative questionnaire consisted of questions about socio-demographics, suicide risk, service delivery characteristics, the satisfaction of received psychosocial help and the approach to their impact. MS Excel 2007 and SPSS 20.0 were used for statistical data analysis.

Results and conclusions. Case management, psychological or support groups and anonymous psychological counseling were rated positively by the majority of persons, who received Kaunas city suicide prevention model services and participated in the research. Participants, who received case management, most noticed positive changes in getting emotional support, increasing knowledge about psychosocial help and reducing suicidal ideation. However, positive changes in solving problems, improving communication skills and personal relationships were least noticed after involvement in case management. The participation in psychological or support groups mostly helped to get more emotional support, to increase knowledge about psychosocial help and hope about problems solved in the future while the least noticed positive changes were in reducing anxiety and stress, improving personal relationships and skills of problems solving. Participants, who had anonymous psychological consultations, were most likely to notice positive changes in getting emotional support, increasing hope about problems solved in the future and improving emotional wellbeing. However, positive changes in improving personal relationships, communication skills and solving problems were least noticed after getting anonymous psychological consultations.

Correspondence to: lina.pranckeviciute@kaunovsb.lt

Gauta 2020-03-13 